\title{
Acer yangbiense (Aceraceae), a New Species from Yunnan, China
}

\author{
Yousheng Chen and Qiner Yang \\ Laboratory of Systematic and Evolutionary Botany, Institute of Botany, Chinese Academy \\ of Sciences, Xiangshan, Beijing 100093, People's Republic of China. \\ maple@ns.ibcas.ac.cn; qeyang@ns.ibcas.ac.cn \\ Guanghua Zhu \\ Missouri Botanical Garden, P.O. Box 299, St. Louis, Missouri 63166-0299, U.S.A. \\ Guanghua.Zhu@mobot.org
}

Abstract. Acer yangbiense Y. S. Chen \& Q. E. Yang, a new species from Yangbi County, Yunnan Province, is described and illustrated. This species is similar to Acer leipoense Fang \& Soong from western Sichuan in having a pale gray abaxial surface of the leaves, a much longer glabrous infructescence and fruiting pedicels, and convex nutlets, but differs by its larger 5-lobed leaves with a cordate base, abaxially densely pubescent veins and veinlets, and pubescent young branchlets and petioles.

Key words: Acer, Aceraceae, China, Yunnan.

In the course of checking specimens of the Chinese Aceraceae in the herbarium of Sichuan University (SZ) in 2001, a specimen from Yangbi County, Yunnan, R. C. Ching 22525, caught our attention. Fang Wen-Pei identified it as Acer kungshanense Fang on the determinavit slip in 1959, although this species was not formally published by him and C. Y. Chang until 1966 (Fang, 1966). At first glance this specimen is somewhat similar to A. kungshanense in having leaves abaxially densely hairy, but differs in having 5-lobed leaves, a pale gray abaxial surface of the leaves, a glabrous infructescence, and convex nutlets. In contrast, $A$. kungshanense has 3-lobed leaves, a yellow-brown abaxial surface of the leaves, a pubescent infructescence, and ovoid-globose nutlets. This specimen is more similar to A. leipoense in having a pale gray abaxial surface of the leaves, a glabrous infructescence, and convex nutlets, but differs by its 5-lobed leaves, which are abaxially densely hairy along the veins and veinlets, and thus may represent an undescribed species. Unfortunately, this specimen is in poor condition, with the infructescence being incomplete, so in April 2002 the first author made an expedition to Yangbi County in northwest Yunnan to collect more specimens. A large tree bearing young fruits was found. Although flowering specimens were unavailable, some fruits that were still bearing perianths and anthers were gathered. This confirmed to the authors that the plant really is a new species.

Acer yanghiense Y. S. Chen \& Q. E. Yang, sp. nov. TYPE: China. Yunnan: Yangbi County, Malutang, forests, alt. 2400 m, 24 Apr. 2002, Y. S. Chen 2010 (holotype, PE; isotypes, MO, $\mathrm{PE})$. Figures 1, 2.

Species A. leipoensi affinis, sed differt foliis majoribus, 10-20 cm longis, 11-25 cm latis, 5-lobatis, basi cordatis, nervis primariis 5 , nervis et venis subtus densissime pubescentibus.

Deciduous tree, up to $20 \mathrm{~m}$ tall; trunk up to 20 $\mathrm{cm}$ diam.; branchlets of the present year greenish, pubescent; branchlets of the previous year browngreen, pale gray pubescent; those more than two years old light brown or dark brown, glabrescent, with noticeable brown-yellow lenticels; winter buds ovoid, dark brown, imbricate scales about 9 pairs, tomentose outside, dropping off soon after the flowers or leaves have matured. Leaves chartaceous, $10-20 \times 11-25 \mathrm{~cm}$, usually broader than long, shallowly 5-lobed, base cordate, deep green above, glabrous, pale green beneath, abaxially very densely pubescent along veins and veinlets; basal lobes usually smaller, apex acuminate, or accidentally absent; middle and lateral lobes triangular-ovate, apex acuminate, entire or remotely toothed with a few sinuous teeth; primary veins 5 , impressed on the upper surface, conspicuously prominent below; central lobe with 7 to 9 pairs of parallel lateral veins; petioles 4-17 cm long, pale gray pubescent. Racemes glabrous, pendulous, arising from leafless lateral buds of 2- or 3-year-old branchlets. Flowers hermaphroditic, yellow-green; sepals 5, ovate-oblong, ca. $4.5 \times 4 \mathrm{~mm}$, yellow-green, glabrous; petals 5, ovate, yellow-green, base narrow. Intrastaminal disk glabrous; stamens 8; filaments ca. 2-3 mm long; anthers ovoid, ca. $1 \mathrm{~mm}$ long; styles 2, base

Novon 13: 296-299. 2003. 


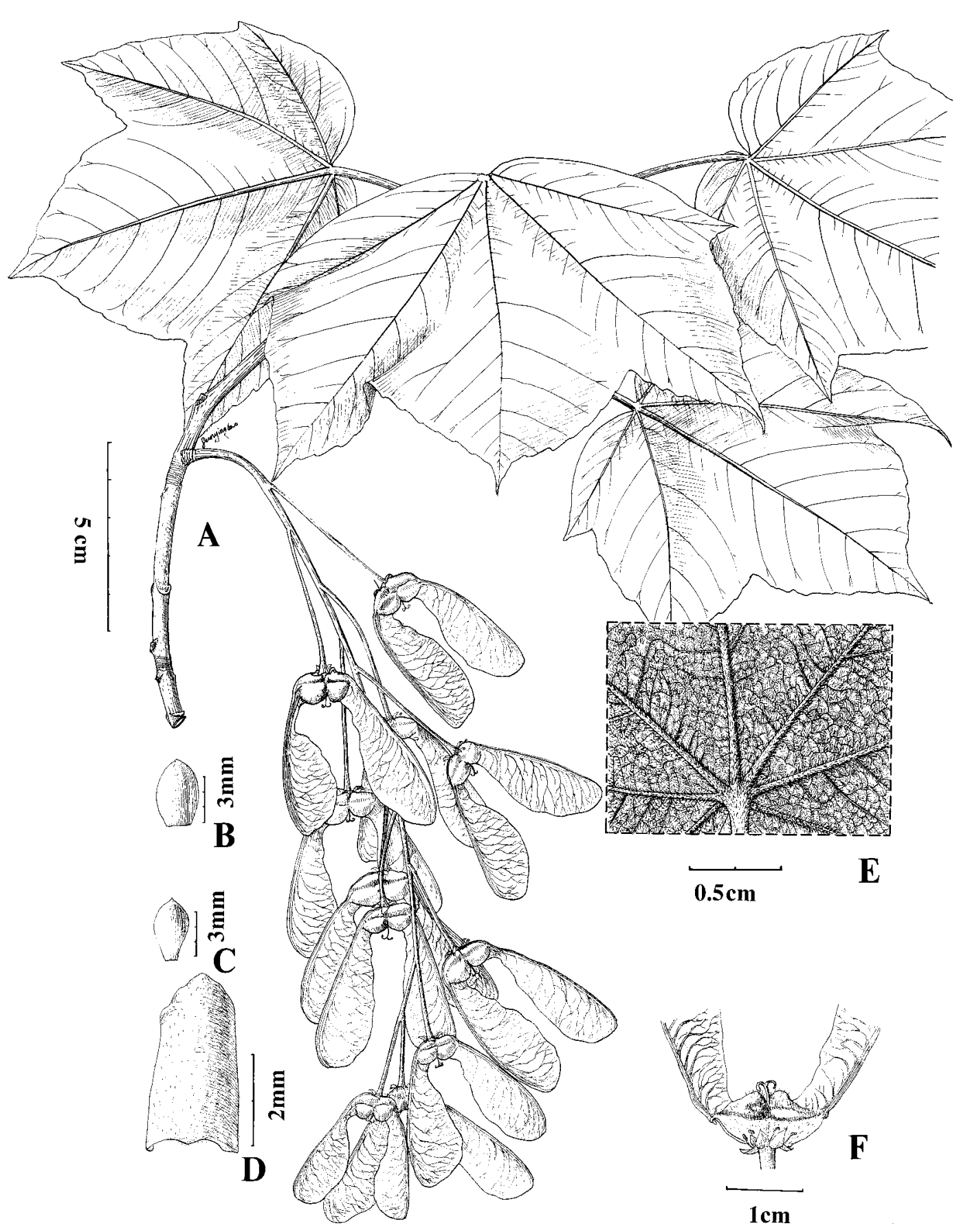

Figure 1. Acer yangbiense Y. S. Chen \& Q. E. Yang. —A. Branch with infructescence. -B. Sepal. —C. Petal. -D. Bud scale. - E. Pubescence on the abaxial surface of leaves. - F. Details of young fruit with persistent stamens. Drawn from Y. S. Chen 2010 (PE).

united, the free portion curved downward; stigmas 2, simple. Infructescence pendulous, ca. 9-32 × 7 $\mathrm{cm}$; fruits 9 to 17 per raceme, red-green when young, brown-yellow when mature; wings together with nutlets $4.7-5.5 \times 1.4-1.7 \mathrm{~cm}$, strongly veined, spreading at acute or nearly right angles; fruiting pedicels 2.7-3.4 cm long, glabrous; nutlets ca. 7 mm diam., middle convex, globose, villous. 

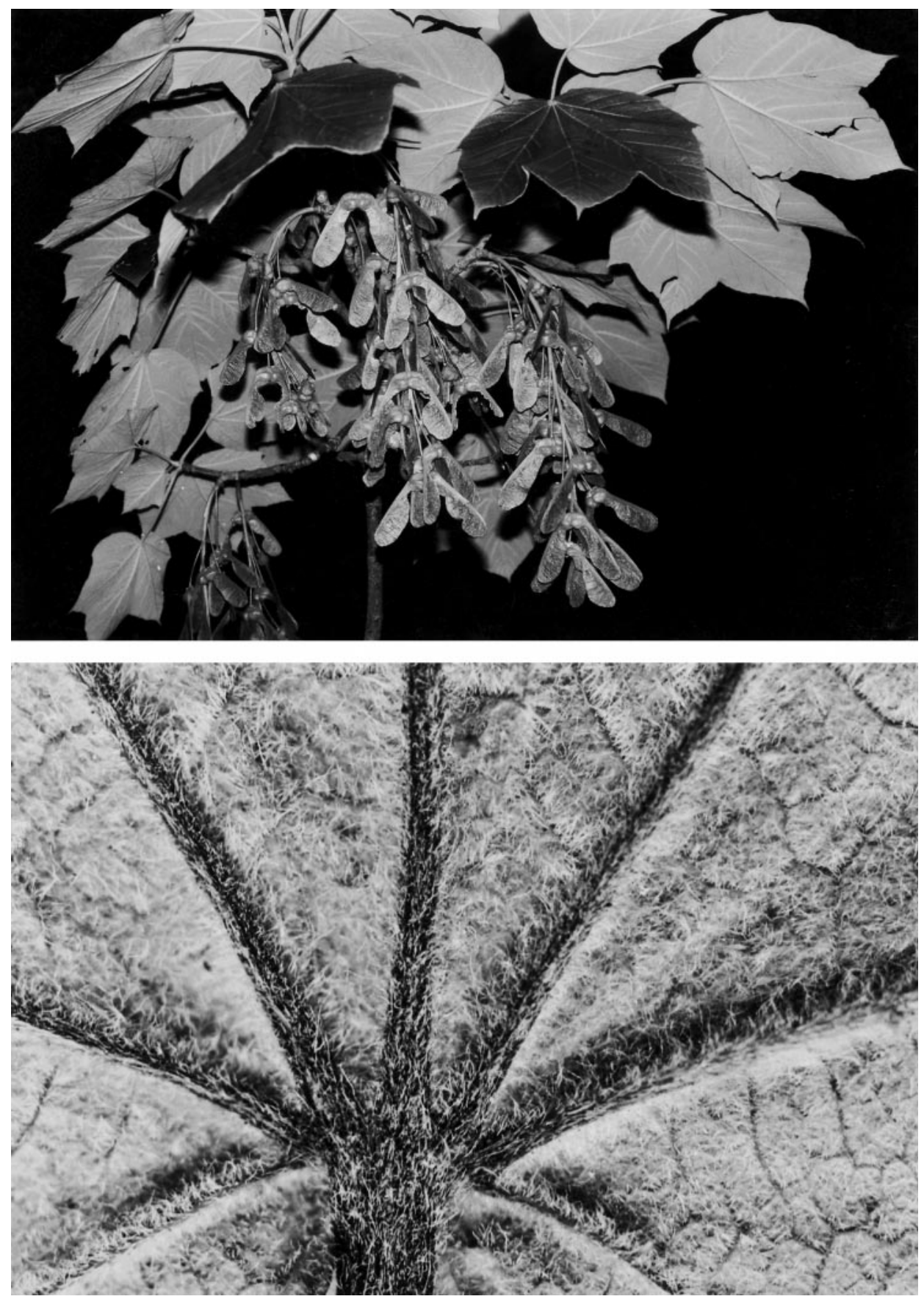

Figure 2. Acer yangbiense.-Above. Fruiting branch. — Below. Pubescence on the abaxial leaf surface. Photographs by Yousheng Chen.

Distribution and habitat. This species seems restricted in distribution. So far it is known only from its type locality, a valley in the western slope of Mt. Cangshan, Yangbi, northwestern Yunnan. Just above this area grows a large forest of Rho- dodendron delavayi Franchet. Its population is small, consisting of no more than 10 trees sparsely scattered near a small village. It is therefore to be considered a rare and endangered species. According the IUCN red list categories and criteria, Ver- 
sion 3.1 (IUCN, 2001), it should be categorized as a critically endangered species.

Taxonomic remarks. According to Ogata (1965), Acer sect. Lithocarpa Pax is characterized by having dioecious flowers, racemose inflorescences from leafless lateral buds, and buds with 8 to 12 pairs of imbricate scales. This section includes a few species with ranges from the Himalayas to Japan. Among them, A. leipoense subsp. leipoense is found only in Leipo County in Sichuan Province, and A. leipoense subsp. leucotrichum Fang only in Baoxing and Tianquan Counties in Sichuan Province. The first author made an expedition to find these two subspecies in western Sichuan in 2001, but failed to find specimens of either one. We have also examined specimens of Aceraceae in the major herbaria in China and found just two specimens each of A. leipoense subsp. leipoense and A. leipoense subsp. leucotrichum. To our knowledge, the two subspecies of A. leipoense are also critically endangered. The two subspecies of $A$. leipoense and A. yangbiense can be distinguished from the remaining species in section Lithocarpa Pax by having a pale gray abaxial surface of the leaves, convex nutlets, and a much longer infructescence and fruiting pedicels.

Acer yangbiense is similar to A. leipoense subsp. leipoense in having a pale gray abaxial surface of the leaves, a long glabrous infructescence and fruiting pedicels, and convex nutlets, but differs by its larger 5-lobed leaves very densely pubescent abaxially along veins and veinlets, and pubescent young branchlets and petioles. Acer leipoense subsp. leucotrichum is different from the new species by its much smaller 3-lobed leaves $(9-11 \times 11-12 \mathrm{~cm})$ and nutlets $(3.5-4.3 \times 0.8-1.3 \mathrm{~cm})$, and shorter fruiting pedicels $(1.8-3 \mathrm{~cm})$. The leaf bases of both subspecies of $A$. leipoense are rounded, while those of $A$. yangbiense are cordate. The leaves of A. leipoense subsp. leucotrichum are abaxially only sparsely pubescent and the hairs cannot be felt with fingers, while the leaves of Acer yangbiense are abaxially so densely pubescent that the hairs can easily be felt. Thus, A. yangbiense can be distin- guished from A. leipoense subsp. leucotrichum by the pubescence character.

The circumscription of Acer sect. Lithocarpa made by de Jong (1994) is almost the same as that made by Ogata (1965) except that de Jong treated A. macrophyllum Pursh in this section as a monospecific series, series Macrophylla Pojárkova ex Momotani, while Ogata treated it as an independent section, section Macrophylla (Pojárkova) Ogata. Acer yangbiense is a member of Acer sect. Lithocarpa ser. Lithocarpa by having racemes arising from leafless lateral buds and about nine pairs of imbricate scales on the buds.

Paratype. CHINA. Yunnan: Yangbi, Ma-lu-tang, 3 May 1929, R. C. Ching 22525 (SZ).

Key to A. yangbiense, A. LeIPoEnse, and A. KUngShanense

la. Abaxial surface of leaves yellow-brown; infructescence 7-9 cm long, glabrous; fruits 4 to 7 per raceme; nutlets globose ...... Acer kungshanense

1b. Abaxial surface of the leaves pale gray; infructescence $10-32 \mathrm{~cm}$ long, \pm pubescent; fruits 9 to 17 per raceme; nutlets convex.

2 a. Leaves $9-11 \times 11-12 \mathrm{~cm}$, sparsely pubescent abaxially along veins and veinlets (hairs cannot be felt with fingers); leaf blade 3 lobed, base rounded; nutlets 3.5-4.3 $\times 0.8-$ $1.3 \mathrm{~cm} \ldots \ldots \ldots \ldots$. . . . . . . leipoense

$2 \mathrm{~b}$. Leaves $10-20 \times 11-25 \mathrm{~cm}$, densely pubescent (hairs can be easily felt with fingers); leaf blade 5-lobed, base cordate; nutlets $4.7-5.5 \times 1.4-1.7 \mathrm{~cm} \ldots .$. Acer yangbiense

Acknowledgments. We thank two anonymous referees for their valuable comments, and Sun Yingbao for his illustration.

\section{Literature Cited}

Fang, W. P. 1966. Revisio taxorum Aceracearum sinicarum. Acta Phytotax. Sin. 11(2): 139-189.

IUCN. 2001. IUCN Red List Categories and Criteria: Vers. 3.l. IUCN Species Survival Commission. IUCN, Gland, Switzerland, and Cambridge, U.K.

Jong, P. C. de. 1994. Taxonomy and reproductive biology of maples. Pp. 69-103 in D. M. van Gelderen, P. C. de Jong, H. J. Oterdoom \& J. R. P. van Hoey Smith (editors), Maples of the World. Timber Press, Portland, Oregeon.

Ogata, K. 1965. A systematic study of the genus Acer. Bull. Tokyo Univ. Forest 63. 89-205. 